\title{
Comparative Analysis of Methods of Molecular Detection of Avian Influenza Virus
}

\author{
Maryna Sapachova* \\ Molecular and Genetic Research Department, State Scientific Research Institute of Laboratory Diagnostics and Veterinary Sanitary \\ Expertise, Kyiv, Ukraine
}

\section{Objective}

The performance of comparative analysis of sensitivity and results of detection of avian influenza virus by real time polymerase chain reaction (PCR-RT) and loop-mediated isothermal amplification of the nucleic acids (LAMP) was the main goal of the study.

\section{Introduction}

As part of this surveillance study for Avian Influenza both active and passive surveillance samples were tested using PCR and also utilized to validate the LAMP method. Active surveillance samples include pathological material and tracheal and cloacal swabs from ill poultry, which were subsequently assessed for avian influenza during diagnosis, and birds collected by hunters. Passive surveillance included environmental samples such as sand and bird faeces. Active surveillance samples were taken mostly from poultry farms across Ukraine, where infected birds are required to be diagnosed by State Scientific Research Institute of Laboratory Diagnostics and Veterinary Sanitary Expertise (SSRILDVSE) by Ukraine Law. Passive surveillance samples were taken primarily during the annual bird migration season. Development of simple, sensitive, and cheap methods for diagnostics of avian influenza is a very important task for practical veterinary medicine. LAMP is one of such methods. The technique is based on isothermal amplification of nucleic acids. It does not require special conditions and equipment (PCR cyclers), therefore it is cheaper in comparison with PCR. Accurate diagnosis is necessary for determining the risk associated with avian influenza in Ukraine and along the Dnipro River during the migratory season.

\section{Methods}

For the research, we used PCR-RT commercial kit Bird-Flu-PCR (Ukrzoovetprompostach, Ukraine), LAMP (the protocol has been optimized and patented by SSRILDVSE), QIAamp ${ }^{\circledR}$ Viral RNA Mini Kit. For the study, we used pathological and biological materials from birds, which were sent to the SSRILDVSE from all regions of Ukraine according to the 2013-2014 State monitoring plan.

Set up of the real time PCR reactions and parameters of amplifications are indicated in the instruction to the kit.

The following protocol was used to set up the RT- LAMP: $2.5 \mu \mathrm{L}$ $10 \mathrm{X}$ Thermopol buffer, $1 \mathrm{mmol} / \mathrm{L}$ betaine, $5 \mathrm{mmol} / \mathrm{L} \mathrm{MgSO} 4$, $1.4 \mathrm{mmol} / \mathrm{L}$ - BNTP, $12.5 \mu \mathrm{mol} / \mathrm{L}$ SYBR GREEN, $0.5 \mathrm{mmol} / \mathrm{L}$ MnCL2, up to $25 \mu \mathrm{L}$ Nuclease-free water, $8 \mathrm{U}$ Bsm DNA polymerase, $0.1 \mu \mathrm{M} / 1$ of $\mathrm{F} 3,0.1 \mu \mathrm{M} / 1$ of B3, $0.8 \mu \mathrm{M} / 1$ of FIP, $0.8 \mu \mathrm{M} / 1$ of BIP, $0.4 \mu \mathrm{M} / 1$ of $\mathrm{LF}, 0.4$ of $\mathrm{LB}, 2 \mu \mathrm{L}$ cDNA.

During our work, we used the following optimal temperature and time for the amplification $-59^{\circ} \mathrm{C}$ and 60 minutes.

The sensitivity of diagnostic kit Bird-Flu-PCR and RT- LAMP was determined by testing cDNA of the reference strain of AIV H5N1, which was provided to us by NSC Institute for Experimental and Clinical Veterinary Medicine (Kharkiv, Ukraine). For the standard, we employed concentration in the range of 10.0-0.01 ng/sample.
This table shows the reproducibility results obtained by both methods. However, taken into account absence of highly pathogenic avian influenza virus circulating in Ukraine during the studied period, it was not possible to confirm these results with protocols of positive samples.

Table 2.

It has been established that the sensitivity of PCR-RT kit Bird-FluPCR is $0.01 \mathrm{ng} / \mathrm{sample}$ for gene $\mathrm{M}$ and $0.1 \mathrm{ng} /$ sample for subtype H5N1.

Fig. 1. Visual detection of LAMP products with different concentrations of cDNA of avian influenza virus (ng per sample)

$1-10 ; 2-5 ; 3-1.0 ; 4-0.1 ; 5-7-0.01 ; 8-9-0.1 ; 10$ - negative.

We have examined the LAMP results using electrophoresis for the confirmation of visual detection and correct interpretation of the results (Fig. 2).

Fig.2. Electrophoresis results for LAMP products. M molecular weight marker; $1-10.0 ; 2-5.0 ; 3-1.0 ; 4-0.1 ; 5-7$ $-0.01 ; 8$ - negative control.

It has been established that the sensitivity of LAMP is $0.1 \mathrm{ng} / \mathrm{sample}$. Slightly lower sensitivity of LAMP in comparison to PCR-RT can be explained by visual detection of the products of the LAMP reaction.

\section{Conclusions}

1. Sensitivity of both methods is high.

2. LAMP is a perspective screening method for the diagnosis of viral infectious diseases supported by confirmation of positive results by PCR-RT.

Table 1. Results of tests of pathological and biological materials from birds by PCR and LAMP conducted in 2013-2014

\begin{tabular}{|c|c|c|c|c|c|}
\hline \multirow{2}{*}{$\#$} & \multirow{2}{*}{ Type of tested material } & \multicolumn{2}{|c|}{$\begin{array}{c}\text { Number of sample } \\
\text { PCR-RT }\end{array}$} & \multicolumn{2}{c|}{$\begin{array}{c}\text { Number of sample } \\
\text { LAMP }\end{array}$} \\
\cline { 3 - 6 } & & Total & Positive & Total & Positive \\
\hline 1 & Pathological material from poultry & 1,100 & 0 & 1,100 & 0 \\
\hline 2 & Tracheal and cloacal swabs & 46 & 0 & 46 & 0 \\
\hline 3 & Sand & 1 & 0 & 1 & 0 \\
\hline 4 & Faeces of birds & 2,217 & 0 & 2,217 & 0 \\
\hline 5 & Total & 3,364 & 0 & 3,364 & 0 \\
\hline
\end{tabular}

Table 2. Sensitivity of PCR-RT kit Bird-Flu-PCR

\begin{tabular}{|c|c|c|}
\hline \multirow{2}{*}{$\begin{array}{c}\text { cDNA concentration, ng } \\
\text { per sample }\end{array}$} & \multicolumn{2}{|c|}{ Ct value } \\
\cline { 2 - 3 } & Gene $\mathbf{M}$ & Subtype H5N I \\
\hline 10 & 26.05 & 22.61 \\
\hline 1 & 30.73 & 26.78 \\
\hline 1 & 30.36 & 26.73 \\
\hline 1 & 30.26 & 26.66 \\
\hline 0.1 & 34.05 & 30.41 \\
\hline 0.1 & 34.99 & 30.40 \\
\hline 0.1 & 34.10 & 33.90 \\
\hline 0.01 & 43.37 & 33.90 \\
\hline 0.01 & 42.33 & 33.59 \\
\hline 0.01 & 36.68 & 33.52 \\
\hline- & - & - \\
\hline+ & 11.45 & 12.50 \\
\hline
\end{tabular}

Results

Table 1. 
ISDS 2016 Conference Abstracts
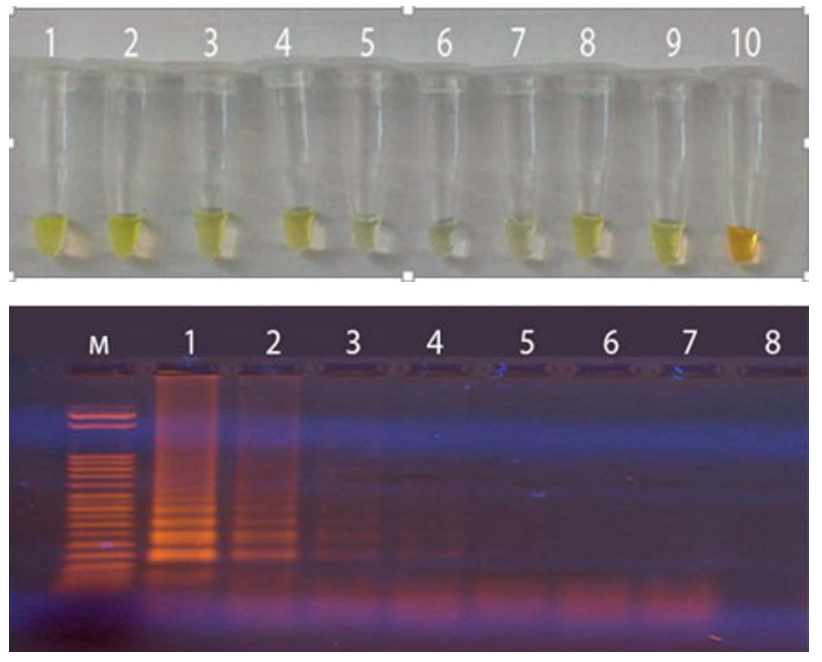

\section{Keywords}

avian influenza virus; PCR; diagnostics; isothermal amplification of the nucleic acid; sensitivity

\section{*Maryna Sapachova}

E-mail: m_sapacheva@meta.ua 